\title{
Ergonomic analysis of workplaces in the iron casting industrial pole in Claudio, Minas Gerais - Brazil
}

\author{
Artur Caron Mottin a, ${ }^{\mathrm{a}}$, Carlos A. Silva de Miranda ${ }^{\mathrm{a}}$, Caroline Salvan Pagnan ${ }^{\mathrm{a}}$ and Olavo Pena Monken ${ }^{\mathrm{a}}$ \\ ${ }^{a}$ CDE, Universidade do Estado de Minas Gerais, Presidente Antônio Carlos Avenue, 4575, São Luiz, Belo \\ Horizonte, Minas Gerais, Brasil
}

\begin{abstract}
Brazil is currently recognized as the 10th largest producer of castings, and the city of Cláudio, MG is known worldwide as the "Greatest foundry and metallurgical pole in Latin America", with more than 80 companies. However, this large number of enterprises and increasing investments in product development has demanded an increase in manpower and working hours of workers in the sector, proportionally increasing the incidence of occupational related health problems like RSI (repetitive strain injury), WMSDs (work-related musculoskeletal disorders) and industrial accidents. This article aims to characterize the industry from previously conducted case studies to relate the main causes of occupational diseases and outline possible interventions through design, showing how this tool can contribute to improve the working environment, workplace, tools and equipment through ergonomics adjustments.
\end{abstract}

Keywords: ergonomics, design, workplace, casting

\section{Introduction}

The Brazilian gray iron processing industry of the manufacture of consumer and industrial goods positions the country among the world's largest producers of cast articles. This sector has been growing with potential for further expansion beyond its importance to the economy of the country and the state with the pole casting composed of five cities in the Midwest of the state, with the city of Claudio, one of the main components of this pole with great participa-tion. These factors make it become necessary studies on the foundry industry to make it more modern and thus more competitive.

The archaic nature of the process employed in the production of articles by the smelting of metals leads to the daily exposure of employees of the component companies of the sector to inadequate working conditions, causing illness, injury and forced the dismissal of employees due to fatigue and disability. This is due to the fact that the component companies of this sector, although acknowledging the importance of investment in technological innovation, do not consider themselves unable to make this investment, aggravating the problems encountered in the functions performed by employees in this productive sector.

This reality could be observed by the visit to companies composing the foundry sector in gray iron in the city of Claudio, in Minas Gerais. This visit allowed a broad observation of working conditions found in companies, and the construction of a diagnosis about the ergonomic conditions of work. From this, analyses were conducted, for which were used the methods of the field research and literature review. In this survey, the main factors observed were working posture, working environment and the interactions between employees and the various equipment used in production.

Through literature review, were studied the statistics related to occupational health problems such as RSI (repetitive strain injury), WMSDs (musculoskeletal disorders related to work) and work accidents.

\footnotetext{
* Corresponding author. E-mail: mottindesign@gmail.com
} 
Allowing also the perception of aspects of possible interference of design, to improve the ergonomics of the work on functions performed along the stages of production. These improvements will bring more comfort to the workers, who will be better able to perform their tasks, which is interesting not only for the employee, but for the company, which will have best results as a reflection.

After the collection of this information, has been made the convergence between the information available in ergonomic studies, the data collected in the field and the methodology of design, which allows the development of solutions or guidelines providing improved working conditions of employees under the aspects that are subject to intervention of design. Making possible better interaction among workers, tools and workplace as a whole, minimizing injuries, stress and fatigue involved in the production of cast iron.

\section{The pole of Claudio - MG/ Brazil}

Brazil is located between the top ten producers of cast articles in the world, employing, in 2001, according to the Brazilian Institute of Geography and Statistics (IBGE, 2002), about 43000 employees, with sales of $\$ 2,3$ billion in the same year [1]. The state of Minas Gerais, specifically, has one of the greatest casting poles of the country, composed by the cities of Divinopolis, Claudio, Itauna, Pará de Minas e Carmo da Mata, according to the Federation of Industries of Minas Gerais - Midwest Regional (FIEMG) [2]. In addition, the state is responsible for $27.5 \%$ of national production of articles by casting, with $40 \%$ of production for export. According to data from the Union Foundry Industry in Minas Gerais (SIFUMG), the state has 398 companies in the foundry industry, with installed capacity of 2 million tons/year, directly employing 76,000 staff, representing 49t/man/year of productivity [3].

The city of Claudio, located in western Minas Gerais, has an area of $632.1 \mathrm{~km}^{2}$ and about 22000 inhabitants and is known worldwide as the "Largest Foundry and Metallurgical Pole in Latin America" According to the Cooperative Purchasing of Metalworkers of Claudio (COCIMEC), the city has 139 companies in the sector (cast iron, aluminum and metal), generating 4,000 jobs, which supply an output of 2,000 tons per month, generating revenues of $\mathrm{R} \$ 12$ million per year [4].
The casting process is one of the oldest methods used in the production of parts of many utilities, covering various sectors. Basically, the process consists in filling a mold with liquid metal by heating. The material constitution of the mold, according to Rossitto (1993), depends on the requirements of the final piece, such as finishing, precision and cost, being possible the variation from synthetic sand (black sand or green sand), cold cure sand, Shell sand, ceramic or lost wax. Subsequent to cooling, the piece takes shape through the solidification of the metal [5]. Although the process is old, its application is still archaic, and, according to MINASFUND (2010), after an interview with several companies in the foundry sector in Minas Gerais, 99\% deemed it necessary to technological innovation, and $40 \%$ declared that effectively invest in technology innovation, being significant the fact that $58 \%$ of them are not doing that investment by admitting that they are not able to do so [6].

\section{Production processes in the steel casting sector}

The methods currently adopted in foundries desrange of the most sophisticated, such as automatic lines, passing through intermediaries such as presses for compression molds, and going to the simplest and the procedures found in the region of Claudio, which are the foundries in green sand.

The casting process consists of pouring (dumping) containing liquid metal into a mold cavity with shape and measures corresponding to the part to be manufactured. The casting also can be subdivided according to the type of force used for the filling of the mold, which can be pressure or gravity, the last one is the most commonly found in the region, using green sand as mold.

The green sand casting process comprises basically the following steps: [12.13]

- Model fabrication (modelation) consists in build a model with the shape of the part to be cast. It serves to build the mold, and its dimensions should include the contraction of the metal when it solidifies, and a allowance for possible subsequent machining of the part. Can be made of wood, metal, plastic, plaster, etc..

- Preparation of the mold (molding) is the device on which the molten metal is placed in order to obtain the desired part. It is made of refractory material and is molded about the model, leaving a cavity in the shape of the piece after removed. 
- Preparation of the core (core making): a device is also made of refractory, which has the finality of forming voids, holes and recesses of the piece. They are placed in the molds before they are closed to receive the liquid metal.

- Fusion: the metal is heated until its merger, leaving the liquid.

- Leakage: is the mold filling with the liquid metal.

- Demoulding: is the removal of the core and the mold after the solidification of the part, can be made manually, or by mechanical means.

- Deburring and cleaning: the removal of the feeding channels and burrs that are formed during casting, and the withdrawal of the inlays in the casting mold, generally by means of abrasive jet.

- Quality control: check the conformity of the part (no defects).

Among all the steps above, the ones which presents major problems in the workplace, ergonomically talking, are molding or preparation of the mold and the casting in of the metal in molds.

However, sectors such as deburring and cleaning mold release and present major problems of workinggas car high physiological demand. These results corroborated the qualitative assessment of workers: employees in the sector of Ejector-age were more dissatisfied than those of Deburring with the working posture and showed greater intensity of back pain [14].

\section{Health problems associated with functions exercised by employees.}

The foundry industry operates by processes that combine strictly manual activities and pro-semiautomated processes, rare in the production line. There is a large share of manual labor in the processing of parts. Many of these activities are extremely repetitive, monotonous and performed in intense rhythms. These are activities carried out under extremely painful, which explain the high incidence of repetitive strain injury (RSI).

In the case of the foundry industry, RSI has achieved mainly workers who perform tasks of preparing the mold (mold), casting, demolding and removal of burrs, present in various mechanical industries.

In the metal mechanic sector, specifically in the process of green sand casting, there are still many industries whose production lines have an over- whelming superiority of manual labor, the so-called "handmade industrialization". The main reason for this dominance is linked to high financial cost for the introduction of advanced technology on the production line, limiting the formation of self-determined activities of the processing in reduced productivity and, consequently, the margin profit. These factors lead workers to remain in positions orthostatic / static, performing repetitive movements for long periods of time in unfavorable environmental conditions-tion, causing varied degrees of physical and mental fatigue, contributing to the emergence of occupational diseases.

Repetitive strain injuries (RSI) / work-related musculoskeletal disorders (WMSDs) are disorders or diseases of the musculoskeletal system, especially of neck and upper limbs, related, proven or not, to work. [15]

It is known that musculoskeletal problems related to labor activities are described since ancient times, passing through several periods later, winning, however, notoriety only at the second half of the twentieth century.

Only after the industrial revolution the worker began to take on the socio-economic status and his illness began to be studied by science.

In case of R.S.I. / DORT (Repetitive Strain Injuries - and Cumulative Trauma Disorders e Work Related Musculoskeletal Disorders), from the second half of the twentieth century proliferated descriptions of populations of workers with musculoskeletal problems related to work. [15]

Musculo-skeletal disorders related to work in Brazil, which became known as Repetitive Strain Injury (RSI), represent the major group of diseases, including occupational diseases in the country. [15]

According to the report on DORT and LER of the ministry of health [16], the main lesions are caused by work done in a fixed position (static work) or repetitive movements, especially of the upper limbs, along with the lack of recovery time after contraction and fatigue (lack of time flexibility, intese rhythm of work). The symptoms range from pain, tingling and numbness at the onset of tendinitis, and other orthopedic problems, mainly in the elbows, wrists, hands and shoulders. Syndromes such as carpal tunnel syndrome, cervical, among others, are also common.

Many ergonomists relate the R.S.I. to the poor conditions in the workplace, in other words, only environmental factors, such as low ambient temperature, inadequate furniture and equipment used in the execution of work activities. However, the emergence of these disorders relate only to the work envi- 
ronment is also ignoring the reality of the worker, not taking into account factos as how the activity is developed, for how many hours, how many time the worker has to rest (breaks), how much has to be produced in each journey, among other factors.

An ergonomic analysis shows the critical points of the work, through study of the real activity of workers, identifying risks and their characteristics to detect disequilibrium found between the job and the man, capable of providing an increased workload and cause negative health consequences. [17]

There are risk factors such as repetition, force and effort, awkward postures, static muscle work, task invariability, shock and impact, mechanical stress, vibration, cold and organizational factors, along factors as intensity, duration and frequency, can cause R.S.I.

The repeatability is considered as the cycle duration less than 30 seconds. [15] It is the risk factor most often mentioned, but it is not the only determinant biomechanical factor, because R.S.I. can also appear unrelated to the repetitiveness, but to charges and static postures. [15]

Invariability of the work refers to the activity that is always the same throughout the workday. Inadequate postures are assumed by the workers to carry out the operations of the duty cycle when the workplace is inadequate. The approach is inadequate when, for example, the body has to fight gravity to keep it. The postures in the workplace will depend on the physical state of man, the arrangement of machines and equipment in the workspace, the characteristics of the environment, the tools and conditions of use, product used, the contents of tasks, the cadence and rhythm of work and the frequency and duration of breaks. The static muscular work occurs when, for example, a limb is held in one position, fighting against gravity, and when the musculoskeletal structures has to bear the weight of the member, as in the case of working with arms raised above the level of the shoulder girdle.

In Brazil, many processes have been lawsuits against companies. These actions show clearly the problematic conditions faced by workers in important centers of the country's meat processing. On behalf of the productivity, companies have committed gross violations labor, working hours as exhaustive. It has also been very high the number of occupational diseases.

\section{Design as tool for improvement of the work ranks.}

As previously mentioned, there are many problems arising from poor working structure of the foundry sector, as well as long time in awkward positions and long working hours, making many repetitive movements and posture causing serious problems. Through Artemis' design can alleviate these problems with seemingly simple solutions.

The design of ergonomics through the tool can operate as a factor in improving stations occupational safety.

Due to unproperly designed machinery, equipments and workspaces the workers are often exposed to to unadequate postures. The redesign of workspaces aims to improve posture, promote reductions in fatigue, body pain and avoid absence from work due to occupational diseases. [7] To illustrate, the picture below shows some real situations of jobs where design and ergonomics were not used. The consequence of this is awkward postures of the operators, causing serious pro-musculoskeletal problems. The task analysis was divided into two distinct parts to achieve better results: molding and leaking.

Both tasks require postures which clearly represents threats to the spine. These positions places the operator with the spine completely bent, holding variable weights and demanding certain time of exposure also varies. In leaking, the commitment is not characterized by full-time exposure, since there is a part of the transport, made with the body and walking straight. The molding (figure 1), in turn, requires almost full time working with the spine bent and twisted at the same time. This requires different postures of the worker during his working hours. [7] Later the workers, compact the sand with their feet in a "dance" frantic, using the body's own weight and a lot of movement of the legs. Finally, a tamper is used consisting of a metal tube of $11 / 2$ "with a square base of approximately $200 \mathrm{~mm} \mathrm{x} 200 \mathrm{~mm}$ with a thickness of $10 \mathrm{~mm}$, steel, weighing about 5 pounds. [18]

After this operation, there is the removal of the metallic frame, mold cleaning, site preparation to receive the next which is done with the spine completely bent. The forms are prepared on the floor to the ankle. These operations are the ones that require longer duration of postural constraints and, consequently, resulting in increased muscle contraction. [7.18] 


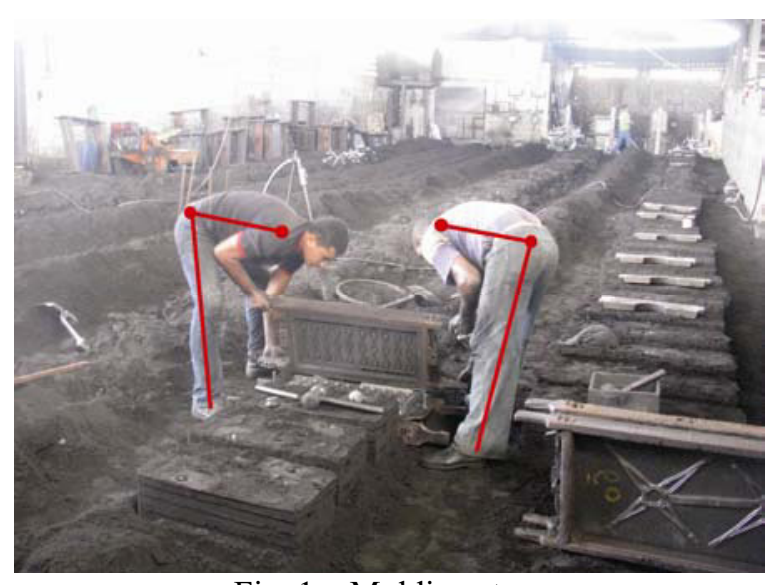

Fig. 1 - Molding step.

The weight lifted is very variable depending on the size of the molded part, which can be 5 pounds and can reach up to 150 pounds. When the product is small, such as pots, feet and rings, the operation is preformed individualy. In the case of plates stoves, the task is performed by two operators, often different in stature. In the pouring process (Figures 2 and 3 ), the operator bend his knees, leaving the body completely bent and twisted to the left or right depending on which side on which the employee is operating the crucible, which offers an overload of the intervertebral discs. [19] This operation is also time varying for each product to be leaked. For the conterweight of an elevator, the, duration is approximately 1 minute and a half, and the small plaque of wood stoves is about 45 seconds [18].

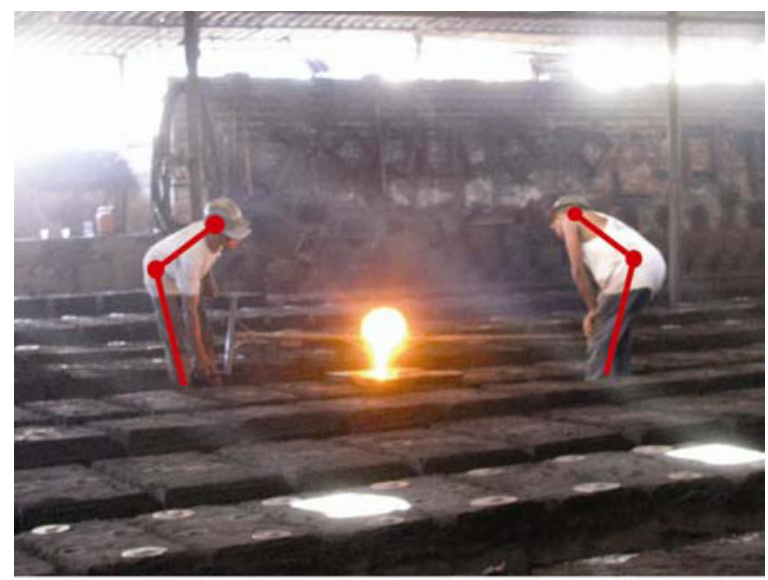

Fig. 2 - Step leak.
The weight of each crucible is filled with $50 \mathrm{~kg}$, operated by two workers. In activity analysis, it was observed that, for the transportation of the molten material, the crucible has a double cable on one side and the other a simple one. This arrangement makes it one of the operators carry it by dividing the weight in the other two arms, while the other worker can only use one arm. This imbalance causes the spine to the transport, which can cause a considerable source of discomfort to intervertebral discs. [20]

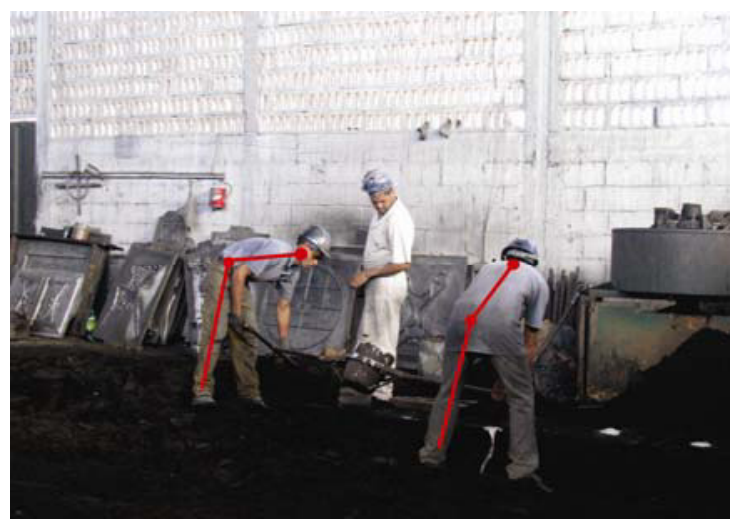

Fig. 3 - Step leak.

\section{Conclusions}

The postural pain in the process of casting lead to musculoskeletal disorders, and, as a consequence, the onset of back pain, and other pathologies commitssations of the spine. [18]

The sand mold compression is usually done manually, it should be done mechanically, with specific equipment available.

It is concluded that the complaints registered have their origin in the posture adopted by employees, which must be corrected by adopting measures such as:

- Make introductory training on posture and postural problems;

- Use people who have stature and physique similar to the process of casting;

- Get up with the legs, let the force be made with the leg muscles which are stronger and more resilient in order to avoid the curvature of the spine; - Insert gymnastics with stretching of the spine and arms as preventive activity;

- Provide short breaks among molders and casters - Verify the possibility of raising the floor plan templates in order to reduce the slope and needed 
spine curvature, both in the molding process and in the process of leak-ing.

These recommendations aim to alleviate the high number of absences from work by the incidence of back pain, developing the well-being at work, work enviroment and improving the production process and its outcome through prevention activities in the workplace.

\section{References}

[1] Instituto Brasileiro de Geografia e Estatística (IBGE) 2002. Available at: < http://www.ibge.gov.br > Accessed: September, 2011.

[2] Federação das Indústrias do Estado de Minas Gerais Regional Centro Oeste (FIEMG). Available at: < http://www. fiemg.org.br/Default.aspx?tabid=1672> Accessed September 20, 2011.

[3] Sindicato da Indústria da Fundição no Estado de Minas Gerais (SIFUMG). Available at: <http://www.sifumg.com.br/>. Accessed September 20, 2011

[4] Cooperativa de Compras das Indústrias Metalúrgicas de Cláudio (COCIMEC). Available at: < http://www.cocimec.com. br/cocimec.php?pg=cidade> Accessed September 20, 2011.

[5] Rossitti, Sergio Mazzer. Processos e Variáveis de Fundição Grupo Metal. Maio, 1993. Available at: < www.grupome tal.com.br/imagens/downloads/grupometal03.pdf> Accessed September 21, 2011.

[6] MINASFUND 2010 - Feira da Indústria da Fundição de Minas Gerais, Belo Horizonte, 2010. Catálogo. Belo Horizonte: 2010 . Available at: $<$ http://issuu.com/netty/docs/minas fund_2010_revista_web\#download $>$ Accessed September 21, 2011 .

[7] Iida, Itiro. Ergonomia: Projeto e Produção. $2^{\mathrm{a}}$ edição revisada e ampliada. São Paulo: Edgard Blücher, 2005.

[8] Kroemer, K. H. E; Grandjean, E. Manual de ergonomia: adaptando o trabalho ao homem. $5^{\mathrm{a}}$ edição. Porto Alegre: Bookman, 2005.

[9] Guérin, F; Laville, A; Daniellou, F; Duraffourg, J; Kerguelen, A. Compreender o trabalho para transformá-lo: a prática da ergonomia. São Paulo: Edgard Blücher, 2004.
[10]Pontes, Herus. A incidência de lombalgia em indústria de fundição: Um estudo de caso sobre a ótica da ergonomia. Dissertação (Mestrado em Engenharia de Produção Universidade Tecnológica Federal do Paraná) Ponta Grossa: 2005.

[11]Diagnóstico da indústria da fundição no Estado de Minas Gerais. - Belo Horizonte: IEL-MG / SIFUMG, 2003. Available at: < www.sifumg.com.br/diagnostico/fundicao.pdf >. Accessed March 2011.

[12] Lesko, Jim. Design industrial: materiais e processos de fabricação.São Paulo: Edgard Blucher, 2004.

[13] Callister, William D. Ciência e Engenharia de Materiais: uma introdução. Rio de Janeiro: LTC, 2002.

[14] Guimarães, Lia Buarque de Macedo; Portich, Paulo; Kmita, Silvério Fonseca. Avaliação quantitativa da carga física de trabalho integrada com a ergonomia participativa em setores de uma fundição. XXIII Encontro Nac. de Eng. de Produção. Ouro Preto, 2003.

[15] Maeno, M. (2001). Reinserção de trabalhadores com lesões por esforços repetitivos no mercado de trabalho. Dissertação de Mestrado, Faculdade de Saúde Pública, Universidade de São Paulo, São Paulo.

[16] Ministério da Saúde. Área Técnica de Saúde do Trabalhador. Lesões por esforço repetitivo (LER), Distúrbios Osteomusculares relacionados ao Trabalho (DORT). Available from http://bvsms.saude.gov.br/bvs/publicacoes/ler dort.pdf $A c$ cessed: 2011-02-26.

[17]Reis, Elcimar da Silva. Análise ergonômica do trabalho associada à cinesioterapia de pausa como medidas preventivas e terapêuticas às LER/DORT em um abatedouro de aves. Florianópolis: UFSC, 2001. Dissertação (mestrado) Programa de pós-graduação em Engenharia de Produção da Universidade Federal de Santa Catarina, Florianópolis, 2001.

[18]Pontes, Herus; Hoss, Osni; Xavier, Antônio A. de Paula. Um fator determinante das dores lombares na indústria de fundição. CAP Accounting and Management - Número 01 Ano 01 - Volume 1-2006.

[19] Grandjean, E. Manual de ergonomia - adaptando o trabalho ao homem. Porto Alegre: Bookman, 1998.

[20] Guérin, F. et al. Compreender o trabalho para transformá-lo - A prática da ergonomia. São Paulo: Edgard Blucher, 2001. 